\title{
Pengaruh Debt To Equity Ratio Dan Return On Equity Terhadap Price To Book Value Ratio Pada PT Ciputra Development Tbk
}

\author{
Amthy Suraya ${ }^{1)}$ dan Tiara Mitra Dona ${ }^{2)}$ \\ ${ }^{1)}$ dosen Universitas Pamulang, email : aya081085@gmail.com
}

\section{ARTICLES \\ INFORMATION}

ABSTRACT

\section{JURNAL SEKURITAS \\ (Saham, Ekonomi, Keuangan dan Investasi ) \\ Vol.3, No.2, Januari 2020 Halaman : $166-175$ \\ () LPPM \& Prodi Manajemen UNVERSITAS PAMULANG \\ ISSN (online) : 2581-2777 ISSN (print) : : 2581-2696}

Keyword :

Debt to Equity Ratio; Price to Book Value dan Return on Equity

JEL. classification :

C33, G21, G24, N15, N25

\section{Contact Author : \\ PRODI MANAJEMEN UNPAM \\ JL.Surya Kencana No.1 \\ Pamulang Tangerang Selatan - Banten \\ Telp. (021) 7412566, Fax (021) 7412491 Email : \\ sekuritas@unpam.ac.id}

Tujuan penelitian ini adalah untuk mengetahui pengaruh Debt To Equity Ratio ( DER ) dan Return On Equity ( ROE ) terhadap Price To Book Value ( PBV ) Pada PT Ciputra Development Tbk. Periode Tahun 2008 - 2017. Dimana variabel independent pada penelitian ini adalah DER dan ROE sedangkan variabel dependentnya adalah PBV. Penelitian ini adalah penelitian asosiatif kuantitatif. Data analisis yang digunakan adalah data sekunder. Metode analisis yang digunakan adalah uji asumsi klasik, uji regresi linear berganda, uji korelasi product moment, uji koefisien determinasi, uji $\mathrm{T}$ dan uji $\mathrm{F}$. Populasi dari penelitian ini adalah laporan keuagan dan sampel penelitian ini adalah neraca dan laporan laba rugi PT Ciputra Develompent Tbk. Hasil Uji $F$ menunjukkan bahwa hasil $F_{\text {hitung }}$ sebesar 10,599 dan nilai signifikan 0,008 , hal ini menunjukkan bahwa DER dan ROE secara simultan berpengaruh signifikan terhadap PBV.

The purpose of this study was to determine the effect of Debt To Equity Ratio (DER) and Return On Equity (ROE) on Price To Book Value (PBV) at PT Ciputra Development Tbk. Period 2008 - 2017. Where the independent variables in this study are DER and ROE while the dependent variable is PBV. This research is a quantitative associative research. The data analysis used is secondary data. The analytical method used is the classical assumption test, multiple linear regression test, product moment correlation test, coefficient of determination test, $T$ test and $F$ test. The population of this study is financial statements and the sample of this study is the balance sheet and income statement of PT Ciputra Develompent Tbk. The results of the $F$ Test shows that the Fcount results of 10,599 and a significant value of 0.008 , this shows that the DER and ROE simultaneously have a significant effect on PBV. 


\section{A. PENDAHULUAN}

Persaingan di dunia bisnis saat ini dirasa semakin ketat. Terlebih lagi bagi Perusahaan yang bergerak pada bidang properti yang ,memiliki banyak pesaing. Namun beberapa tahun kebelakang puncaknya pada tahun 2017, tidak dapat dipungkiri bisnis bidang properti sedang mengalami penurunan atau stagnan. Hal ini dapat di lihat lewat data - data penjualan perusahaan properti yang sudah go public atau tbk ( terbuka ). Sebagian besar tidak mencapai target, sebagian kecil stagnan dan hanya beberapa yang meningkat. Menurut Survei Harga Properti Residensial Bank Indonesia ( BI ) kuartal tiga ( Q3 ) 2017 yang dilakukan secara tatap muka dengan responden para pengembang di 16 kota besar di Indonesia, pertumbuhan penjualan rumah turun dari 3,61\% menjadi $2,58 \%$ dibanding kuartal sebelumnya. Debt to Equity Ratio ( DER ) merupakan salah satu rasio keuangan yang mengukur seberapa besar kemampuan perusahaan melunasi utang dengan modal yang dimiliki. Debt to Equity Ratio ( DER ) yang tinggi menunjukkan bahwa perusahaan sangat bergantung pada pihak luar dalam mendanai kegiatan sehingga beban perusahaan juga akan meningkat. Return On Equity ( ROE ) merupakan salah satu rasio profitabilitas yang menggambarkan kemampuan perusahaan untuk menghasilkan laba bagi pemegang saham atas modal yang mereka investasikan dalam perusahaan. Return On Equity ( ROE ) merupakan suatu pengukuran dari penghasilan ( income ) atas modal yang diinvestasikan dalam perusahaan. Nilai perusahaan salah satunya dapat diukur menggunakan Price to Book Value Ratio ( PBV ). Price to Book Value Ratio ( PBV ) digunakan untuk menilai harga saham perusahaan dengan membandingkan antara harga pasar saham dengan nilai buku ( book value ) perusahaan.

Penulis menggunakan objek penelitian PT Ciputra Development Tbk. Dimulai pada tanggal 22 Oktober 1981, Dr. ( HC ) Ir. Ciputra mendirikan perusahaan dengan nama PT Citra Habitat Indonesia dan pada tahun 1990 mengubah nama perusahaan menjadi PT Ciputra Development Tbk, yang kemudian dikenal sebagai salah satu perusahaan properti terdepan dan paling terdiversifikasi di Indonesia.

Secara konsisten, Perseroan terus menawarkan konsep unik dan modern dalam seluruh arsitektur bangunan yang dikembangkannya dimana hal tersebut merupakan sebuah keunggulan tersendiri dalam proyek pengembangan perumahan dan properti komersial.

Berdasarkan Anggaran Dasar Perusahaan, ruang lingkup kegiatan PT Ciputra Development Tbk adalah mendirikan dan menjalankan usaha di bidang pembangunan dan pengembangan perumahan ( real estat ), rumah susun, apartemen, perkantoran, pertokoan, pusat niaga, tempat rekreasi dan kawasan wisata beserta fasilitas - fasilitasnya serta mendirikan dan menjalankan usaha - usaha dibidang yang berhubungan dengan perencanaan, pembuatan serta pemeliharaan sarana perumahan, termasuk tapi tidak terbatas pada lapangan golf, klub keluarga, restoran dan tempat hiburan lain beserta fasilitas - fasilitasnya.

Sampai saat ini, Perseroan telah mengembangkan sekitar 76 proyek yang meliputi perumahan, apartemen, pusat perbelanjaan, hotel, lapangan golf, rumah sakit dan perkantoran yang tersebar di lebih dari 33 kota besar di seluruh Indonesia.

Dengan sejumlah portofolio dan lahan besar yang dimilikinya, Perseroan telah memperoleh kepercayaan dari masyarakat luas selama lebih dari tiga dekade dan menjadi perusahaan properti terkemuka di Indonesia.

Berikut adalah data mengenai Debt to Equity Ratio ( DER ) dan Return On Equity (ROE) Terhadap Price to Book Value Ratio ( PBV ) pada PT Ciputra Development Tbk. Periode Tahun 2008 - 2017 yang telah diolah oleh penulis. 
Tabel 1. Data DER, ROE, dan PBV PT. Ciputra Development Tbk

\begin{tabular}{|l|l|l|l|}
\hline Tahun & DER & ROE & PBV \\
\hline 2008 & 0,23 & $6,03 \%$ & 0,09 \\
\hline 2009 & 0,23 & $3,27 \%$ & 0,26 \\
\hline 2010 & 0,29 & $5,37 \%$ & 0,73 \\
\hline 2011 & 0,51 & $6,46 \%$ & 1,07 \\
\hline 2012 & 0,77 & $10,02 \%$ & 1,43 \\
\hline 2013 & 1,06 & $14,47 \%$ & 1,16 \\
\hline 2014 & 1,04 & $15,71 \%$ & 1,66 \\
\hline 2015 & 1,01 & $13,34 \%$ & 1,72 \\
\hline 2016 & 1,03 & $8,19 \%$ & 1,44 \\
\hline 2017 & 1,05 & $6,59 \%$ & 1,42 \\
\hline
\end{tabular}

Berdasarkan latar belakang di atas maka penulis tertarik untuk menulis tentang skripsi yang berjudul "Pengaruh Debt To Equity Ratio ( DER ) Dan Return On Equity ( ROE ) Terhadap Price To Book Value Ratio ( PBV ) Pada PT Ciputra Development Tbk. Periode Tahun 2008 - 2017"

\section{B. KAJIAN LITERATUR}

\section{Manajemen Keuangan}

Menurut James S Van Horne dalam buku Pengantar Manajemen Keuangan ( Kasmir : 2009 ) mendefinisikan manajemen keuangan adalah segala aktivitas yang berhubungan dengan perolehan, pendanaan dan pengelolaan aktiva dengan beberapa tujuan menyeluruh.

\section{Price To Book Value}

Menurut Mindra dan Erawati dalam buku Kajian Riset Akuntansi ( Hery : 2017 ), Price to Book Value ( PBV ) adalah rasio pebandingan harga saham dan nilai buku ekuitas perusahaan, yang mengukur nilai yang diberikan pasar kepada manajemen dan organisasi sebagai sebuah perusahaan yang terus tumbuh. Price to Book Value ( PBV ) sering digunakan sebagai acuan dalam menentukan nilai suatu saham relatif terhadap harga pasarnya.

Rumus untuk mencari Price to Book Value ( PBV ) dapat digunakan sebagai berikut :

Price to Book Value $=\frac{\text { Harga Saham }}{\text { Nilai Buku }}$
Nilai Buku $=\frac{\text { Ekuitas }}{\text { Jumlah Lembar Saham Beredar }}$

\section{Return On Equity}

Menurut Irham Fahmi ( 2012 ), Return On Equity ( ROE ) adalah rasio yang digunakan untuk mengkaji sejauh mana suatu perusahaan mempergunakan sumber daya yang dimiliki untuk mampu memberikan laba atas ekuitas.

Rumus untuk mencari Return On Equity ( ROE ) dapat digunakan sebagai berikut :

$$
\text { Return On Equity }=\frac{\text { EAT }}{\text { Ekuitas }} \times 100 \%
$$




\section{Debt To Equity Ratio}

Menurut Kasmir ( 2012 ), Debt To Equity Ratio ( DER ) merupakan rasio yang digunakan untuk menilai hutang dan ekuitas. Rasio ini dicari dengan cara membandingkan antara seluruh hutang, termasuk hutang lancar dengan seluruh ekuitas. Rasio ini berguna untuk mengetahui jumlah dana yang disediakan peminjam ( kreditor ) dengan pemilik perusahaan. Dengan kata lain, rasio ini berfungsi untuk mengetahui setiap rupiah modal sendiri yang dijadikan untuk jaminan hutang.

Rumus untuk mencari Debt To Equity Ratio ( DER ) dapat digunakan pebandingan antara total hutang dengan total ekuitas sebagai berikut :

$$
\text { Debt to Equity Ratio }=\frac{\text { Total Hutang }}{\text { Ekuitas }}
$$

\section{METODOLOGI PENELITIAN}

Metode analisa data dalam penelitian ini adalah metode deskriptif kuantitatif yaitu dengan melakukan pengolahan data - data finansial perusahaan dalam bentuk laporan keuangan.

Metode analisa yang digunakan dalam penelitian ini adalah dengan menggunakan metode SPSS ( Statistical Product Service and Solution ). SPSS merupakan program atas software yang digunakan untuk mengolah data statistik. Rumus data yang digunakan peneliti dalam menyusun penelitian ini yaitu Uji Asumsi Klasik, Uji Regresi Linear Berganda, Uji Korelasi Produk Moment, Uji Hipotesis.

\section{HASIL DAN PEMBAHASAN}

1. Uji Asumsi Klasik

a. Uji Normalitas

Hasil Uji Normalitas

One-Sample Kolmogorov-Smirnov Test

\begin{tabular}{|l|r|r|r|}
\hline & \multicolumn{1}{|c|}{ DER } & \multicolumn{1}{c|}{ ROE } & \multicolumn{1}{c|}{ PBV } \\
\hline $\mathrm{N}$ & 10 & 10 & 10 \\
Norm Mean & .7220 & 8.9450 & 1.0980 \\
$\mathrm{al} \quad$ Std. Deviation & .36799 & 4.24967 & .56686 \\
Para & & & \\
meter & & & \\
$\mathrm{s}^{\mathrm{a}, \mathrm{b}}$ & .283 & .210 & .215 \\
Most Absolute & .180 & .210 & .136 \\
Extre Positive & -.283 & -.149 & -.215 \\
me Negative & & & \\
Differ & .895 & .665 & .680 \\
ences & .399 & .769 & .744 \\
Kolmogorov-Smirnov Z & & \\
Asymp. Sig. (2-tailed) & & & \\
\hline
\end{tabular}

a. Test distribution is Normal.

b. Calculated from data. 
Dari hasil tabel di atas dapat dilihat nilai dari hasil uji lebih besar dari 0,05 maka dapat dikatakan data berdistribusi normal.

b. Uji Multikolinearitas

\section{Hasil Uji Multikolinearitas}

Coefficients $^{\mathrm{a}}$

\begin{tabular}{|c|c|c|c|c|c|c|c|}
\hline \multirow[b]{2}{*}{ Model } & \multicolumn{2}{|c|}{$\begin{array}{l}\text { Unstandardize } \\
\text { d Coefficients }\end{array}$} & \multirow{2}{*}{$\begin{array}{c}\text { Standa } \\
\text { rdized } \\
\text { Coeffic } \\
\text { ients }\end{array}$} & \multirow[b]{2}{*}{$\mathrm{T}$} & \multirow[b]{2}{*}{ Sig. } & \multicolumn{2}{|c|}{$\begin{array}{l}\text { Collinearity } \\
\text { Statistics }\end{array}$} \\
\hline & B & $\begin{array}{l}\text { Std. } \\
\text { Error }\end{array}$ & & & & $\begin{array}{l}\text { Toler } \\
\text { ance }\end{array}$ & VIF \\
\hline $\begin{array}{l}1 \text { (Constant } \\
\text { ) }\end{array}$ & .079 & .227 & & .346 & .739 & & \\
\hline DER & 1.295 & .395 & .841 & 3.276 & .014 & .430 & 2.327 \\
\hline ROE & .009 & .034 & .070 & .275 & .792 & .430 & 2.327 \\
\hline
\end{tabular}

a. Dependent Variable: PBV

Dari hasil uji multikolinearitas di atas diperoleh nilai Tolerance semua variabel $>0,10$ dan nilai VIF semua variabel $<10$, maka dapat disimpulkan bahwa tidak terjadi gejala multikolinearitas dalam model regresi.

c. Uji Heteroskedastisitas

\section{Grafik Scatterplot}

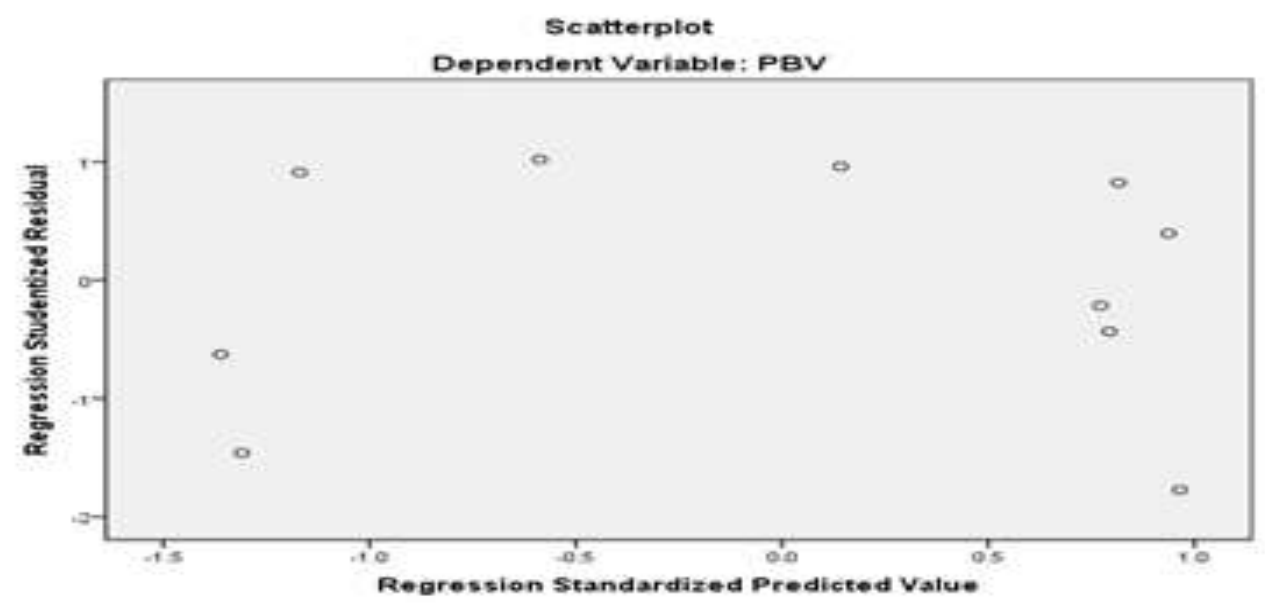

Pada gambar di atas dapat dilihat bahwa titik - titik menyebar secara acak, tidak membentuk pola tertentu dan tidak bertumpuk. Hal ini mengidentifikasikan bahwa tidak terjadi heteroskedastisitas atau data mememenuhi uji asumsi klasik heteroskedastisitas. 
d. Uji Autokorelasi

Uji Autokorelasi dengan Durbin - Watson Model Summaryb

\begin{tabular}{|l|c|r|r|r|r|}
\hline & & $\begin{array}{c}\mathrm{R} \\
\text { Model }\end{array}$ & $\begin{array}{c}\text { Adjusted } \\
\text { R Square }\end{array}$ & $\begin{array}{c}\text { Std. Error } \\
\text { of the } \\
\text { Estimate }\end{array}$ & $\begin{array}{c}\text { Durbin- } \\
\text { Watson }\end{array}$ \\
\hline 1 & \multicolumn{1}{|c|}{$895^{\mathrm{a}}$} & .802 & .745 & .28615 & 1.742 \\
\hline
\end{tabular}

a. Predictors: (Constant), ROE, DER

b. Dependent Variable: PBV

Uji Runs Test
Runs Test
\begin{tabular}{|l|r|}
\hline & \multicolumn{1}{c|}{ Unstandardized Residual } \\
\hline Test Value & .01825 \\
Cases < Test Value & 5 \\
Cases >= Test Value & 5 \\
Total Cases & 10 \\
Number of Runs & 5 \\
Z & -.335 \\
Asymp. Sig. (2-tailed) & .737 \\
\hline
\end{tabular}

a. Median

Dari tabel di atas diketahui nilai DW 1,742 > dari nilai dU 1,641, maka dapat disimpulkan data tidak terjadi autokorelasi. Hal ini juga di diperkuat dengan hasil Run Test, dimana nilai signifikan 0,737 >0,05.

\section{Uji Regresi Linear Berganda}

Hasil Analisis Regresi Linear Berganda

Coefficients ${ }^{\mathrm{a}}$

\begin{tabular}{|l|r|r|r|r|r|}
\hline \multirow{2}{*}{ Model } & \multicolumn{2}{|c|}{$\begin{array}{c}\text { Unstandardized } \\
\text { Coefficients }\end{array}$} & $\begin{array}{c}\text { Standardized } \\
\text { Coefficients }\end{array}$ & & \multirow{2}{*}{} \\
\cline { 2 - 5 } & \multicolumn{1}{|c|}{$\mathrm{B}$} & \multicolumn{1}{c|}{$\begin{array}{c}\text { Std. } \\
\text { Error }\end{array}$} & \multicolumn{1}{c|}{ Beta } & \multicolumn{1}{c|}{ Sig. } \\
\hline 1 (Constant) & .079 & .227 & & .346 & .739 \\
DER & 1.295 & .395 & .841 & 3.276 & .014 \\
ROE & .009 & .034 & .070 & .275 & .792 \\
\hline
\end{tabular}

a. Dependent Variable: PBV

Dari tabel di atas doperoleh ersamaan regresi linear berganda sebagai berikut : $Y=$ $0,079+1,295$. x1+0,009 . x2 . Persamaan linear berganda di atas mempunyai arti dimana karena nilai koefisiennya bernilai positif maka terjadi hubungan yang positif antara DER dan ROE terhadap PBV.

\section{Uji Hipotesis}

a. Uji Koefisien Determinasi 


\section{Hasil Koefisisen Determinasi}

Model Summary ${ }^{\mathrm{b}}$

\begin{tabular}{|l|c|r|r|r|r|}
\hline Model & $\mathrm{R}$ & \multicolumn{1}{c|}{$\mathrm{R}$} & $\begin{array}{c}\text { Adjusted } \\
\text { Square }\end{array}$ & $\begin{array}{c}\text { Rtd. Error } \\
\text { of the } \\
\text { Estimate }\end{array}$ & $\begin{array}{c}\text { Durbin- } \\
\text { Watson }\end{array}$ \\
\hline 1 & $.895^{\mathrm{a}}$ & .802 & .745 & .28615 & 1.742 \\
\hline
\end{tabular}

\section{a. Predictors: (Constant), ROE, DER \\ b. Dependent Variable: PBV}

Berdasarkan Tabel "Model Summary" besarnya nilai pengaruh variabel ditujukan oleh $R^{2}=0,802$ maka $\left(K D=r^{2} \times 100 \%=0,802 \times 100 \%=80,2 \%\right)$ jadi dapat disimpulkan bahwa DER dan ROE berpengaruh sebesar $80,2 \%$ terhadap PBV, sedangkan sisanya $19,8 \%$ dipengaruhi oleh variabel lain yang tidak diteliti di dalam penelitian ini.

b. Uji T ( Parsial )

\section{Hasil Pengujian Uji T \\ Coefficients $^{\mathrm{a}}$}

\begin{tabular}{|c|c|c|c|c|c|}
\hline \multirow[b]{2}{*}{ Model } & \multicolumn{2}{|c|}{$\begin{array}{l}\text { Unstandardized } \\
\text { Coefficients }\end{array}$} & \multirow{2}{*}{$\begin{array}{c}\begin{array}{c}\text { Standardized } \\
\text { Coefficients }\end{array} \\
\text { Beta } \\
\end{array}$} & \multirow[b]{2}{*}{$\mathrm{T}$} & \multirow[b]{2}{*}{ Sig. } \\
\hline & $B$ & $\begin{array}{l}\text { Std. } \\
\text { Error }\end{array}$ & & & \\
\hline 1 (Constant) & .079 & .227 & & .346 & .739 \\
\hline DER & 1.295 & .395 & .841 & 3.276 & .014 \\
\hline ROE & .009 & .034 & .070 & .275 & .792 \\
\hline
\end{tabular}

a. Dependent Variable: PBV

Berdasarkan hasil Uji T di atas diperoleh nilai $t_{\text {hitung }}$ pada variabel DER sebesar 3,276 lebih besar dari $t_{\text {tabel }}$ sebesar 2,365 dan nilai signifikan sebesar 0,014 di mana nilai 0,014 $<0,05$ sehingga Ha diterima yang artinya DER berpengaruh signifikan terhadap PBV . Sedangkan nilai $t_{\text {hitung }}$ pada variabel $R O E$ sebesar 0,275 lebih kecil dari $t_{\text {tabel }}$ sebesar 2,365 dan nilai signifikan sebesar 0,792 di mana nilai 0,792 >0,05 sehingga Ha ditolak yang artinya ROE tidak berpengaruh signifikan terhadap PBV. 
c. Uji F ( Simultan )

\section{Hasil Pengujian Uji F}

\begin{tabular}{|ll|r|r|r|r|r|}
\hline \multicolumn{1}{|c|}{ ANOA $^{\mathbf{b}}$} \\
\hline & $\begin{array}{r}\text { Sum of } \\
\text { Squares }\end{array}$ & Df & $\begin{array}{c}\text { Mean } \\
\text { Square }\end{array}$ & F & Sig. \\
\hline 1 & Regression & 2.319 & 2 & 1.159 & 14.159 & $.003^{\mathbf{a}}$ \\
& Residual & -573 & 7 & .082 & & \\
& Total & 2.892 & 9 & & & \\
\hline
\end{tabular}

a. Predictors: (Constant), ROE, DER

b. Dependent Variable: PBV

Uji $F$, menunjukkan bahwa nilai $F_{\text {hitung }}$ sebesar 14,159 dengan nilai signifikan sebesar 0,003 . Sedangkan untuk $F_{\text {tabel }}$ dengan jumlah sample $(n)=10$, jumlah variabel $(k)=3$, taraf signifikan $\alpha=0,05$, df $1=k-1=3-1=2$ dan df $2=n-k=10-3=7$ diperoleh nlai $F_{\text {tabel }} 4,74$ sehingga $F_{\text {hitung }}>F_{\text {tabel }}$ dan nilai signifikan sebesar 0,003 . Nilai signifikan lebih kecil dari taraf signifikan $(0,003<0,05)$, dengan demikian Ha diterima. Hal ini menunjukkan bahwa Debt To Equity Ratio dan Return On Equity secara simultan berpengaruh signifikan terhadap Price To Book Value.

\section{E. KESIMPULAN}

\section{Kesimpulan}

Berdasarkan pembahasan dan penelitian mengenai pengaruh Debt To Equity Ratio ( DER ) dan Return On Equity ( ROE ) terhadap Price To Book Value ( PBV ) pada PT Ciputra Development Tbk Periode Tahu 2008 sampai dengan 2017, maka dapat diperoleh beberapa kesimpulan sebagai berikut :

1. Debt To Equity Ratio ( DER ) berpengaruh positif dan signifikan terhadap Price To Book Value ( PBV ). Hal ini dapat dilihat dari hasil Uji T ( Uji Parsial ) yang menunjukkan nilai $t_{\text {hitung }}(3,276)>$ nilai $t_{\text {tabel }}(2,365)$ dan nilai signifikan $0,014<0,05$ dengan demikian Ho ditolak dan Ha diterima.

2. Return On Equity ( $\mathrm{ROE}$ ) berpengaruh negatif dan tidak signifikan terhadap Price To Book Value ( PBV ). Hal ini dapat dilihat dari hasil Uji T ( Uji Parsial ) yang menunjukkan nilai $t_{\text {hitung }}(0,275)<$ nilai $t_{\text {tabel }}(2,365)$ dan nilai signifikan 0,792 $>0,05$ dengan demikian Ho diterima dan Ha ditolak.

3. Debt To Equity Ratio ( DER ) dan Return On Equity ( ROE ) berpengaruh positif dan signifikan terhadap Price To Book Value ( PBV). Hal ini dapat dilihat dari hasil Uji F, menunjukkan bahwa nilai $F_{\text {hitung }}(14,159)>F_{\text {tabel }}(4,74)$ dan nilai signifikan $0,003<0,05$ dengan demikian Ho ditolak dan Ha diterima.

\section{Saran}

Adapun saran yang dapat diberikan peneliti atas penelitian yang telah dilakukan adalah sebagai berikut :

1. Bagi perusahaan guna meningkatkan kepercayaan para pemegang saham, maka perusahaan harus mampu menunjukkan kinerja dan nilai perusahaan yang baik dan memberikan penyampaian informasi yang sangan jelas dan terpercaya kepada investor mengenai perkembangan perusahaan.

2. Bagi pihak investor disarankan untuk terlebih dahulu melakukan analisis dan pengamatan guna mempertimbangkan perusahaan mana yang teoat utuk menambahkan investasi modalnya. Setiap investor tentu akan menginginkan perusahaan yang dapat memberikan keuntungan dan memiliki prospek yang baik. 


\section{DAFTAR PUSTAKA}

Abdul Kadim, K., \& Nardi, S. (2018). Eviews Analysis: Determinant of Leverage and Company's Performance. Global and Stochastic Analysis (GSA), 5(7), 249-260.

Fahmi, I. (2012). Analisis Laporan Keuangan Cetakan Kedua. Bandung: Alfabeta.

Hakim, H., \& Sunardi, N. (2017). Determinant of leverage and it s implication on company value of real estate and property sector Listing In IDX Period of 2011-2015, Man in India, vol: 97 , issue : 24,

Harmono. (2009). Manajemen Keuangan Berbasis Balanced Scorecard Pendekatan Teori, Kasus, dan Riset Bisnis. Jakarta: Bumi Aksara.

Hery. (2017). Kajian Riset Akuntansi Mengulas Berbagai Hasil Penelitian Terkini Dalam Bidang Akuntansi Dan Keuangan . Jakarta: Grasindo.

Ismail, S. (2009). Pengantar Manajemen. Jakarta: Erlangga.

Kadim, A., \& Sunardi, N. (2019). Pengaruh Profitabilitas, Ukuran Perusahaan Terhadap Leverage Implikasi Terhadap Nilai Perusahaan Cosmetics and Household yang terdaftar di Bursa Efek Indonesia. Jurnal SEKURITAS (Saham, Ekonomi, Keuangan dan Investasi), 3(1), 22-32.

Kasmir. (2012). Analisis Laporan Keuangan. Jakarta: Rajawali Pers.

Mamduh, H. (2012). Analisis Laporan Keuangan. Yogyakarta: STIM YKPN.

Marlina, T. (2013). Pengaruh Earning Per Share, Return On Equity, Debt to Equity Ratio dan Size Terhadap Price to Book Value. STIE Kesatuan Bogor.

Musthafa. (2017). Manajemen Keuangan. Yogyakarta: CV Andi Offset.

Nuraeni, N. (2017). . Pengaruh Profitabilitas, Likuiditas dan Kebijakan Hutang Terhadap Nilai Perusahaan Pada PT Indofood Sukses Makmur Tbk. Universitas Pamulang.

Oktaviana, D. (2018). Pengaruh Debt to Equity Ratio dan Return On Equity Terhadap Nilai Perusahaan ( PBV ) Studi Kasus 6 Perusahaan Properti / Real Estate Tbk. Universitas Pamulang.

Peatriex, P. (2014). Analisis Pengaruh Debt to Equity Ratio ( DER ), Return On Equity (ROE) dan Earning Per Share ( EPS ) terhadap Nilai Perusahaan. Perbanas Institute.

Prasetyorini, B. (2013). Pengaruh Ukuran Perusahaan, Leverage, Price Earning Ratio dan Profitabilitas Terhadap Nilai Perusahaan. Universitas Negeri Suraya.

Santoso, S. (2011). Analisis SPSS Pada Statistik Parametik. Jakarta: PT Elex Media.

Sugiyono. (2016). Metode Penelitian Kuantitatif Kualitatif dan R\&D. Bandung: Alfabeta.

Sunardi, N. (2019, January). Relevansi Struktur Kepemilikan Tentang Profitabilitas Dan Nilai Perusahaan (Studi pada Industri Manufaktur yang Terdaftar di Bursa Efek Indonesia Periode 2010-2017). In Proceedings (Vol. 1, No. 1). 
Sunardi, N., \& Permana, R. D. I. (2019). Faktor-Faktor Yang Mempengaruhi Harga Saham Dan Dampaknya Pada Nilai Perusahaan (Studi Kasus pada Perusahaan Sub Sektor Pertambangan Minyak dan Gas Bumi yang Terdaftar di Bursa Efek Indonesia Tahun 2013-2017). JIMF (Jurnal IImiah Manajemen Forkamma), 2(2).

Sunardi, N., \& Sasmita, A. S. (2019). Pengaruh Likuiditas, Leverage Dan Growth Terhadap Kinerja Industri Makanan Dan Minuman Yang Tercatat Di Indonesia Stock Exchange Selama Periode Tahun 2011-2015. Jurnal Sekuritas (Saham, Ekonomi, Keuangan dan Investasi), 2(2), 81-97.

Sutrisno. (2012). Manajemen Keuangan Teori, Konsep dan Aplikasi. Yogyakarta: Ekonisia.

Wijaya, D. (2017). Manajemen Keuangan Konsep dan Penerapannya. Jakarta: Grasindo. 